\title{
Title Index of Volume 3
}

\section{EDITORIALS}

\section{LETTERS TO THE EDITOR UNITED NATIONS ACTIVITIES}

Special Report: UN General Assembly (R. G. Tanguay)

The Law of the Sea Conference - Success or failure?

(C. A. Fleischer)

Fifth Session of Senior Advisors to ECE Governments (R. Connelly and C. Ducret)

Shared Natural Resources (R. G. Tanguay)

UNEP: Malta Centre

Split: "Plan Bleu" pour la Méditerranée ("Blue Plan" for the Mediterranean)

UNEP: 5 th Governing Council (H. Mitchell)

UNEP's Critics Explain

New Faces

Tolba: UNEP to Concentrate Efforts

Global Environment Threatened

Protecting Endangered Species

Desertification Report

Developing Environmental Law

Environment Fund

Environment and Development

Making Earthwatch Work

Protection for the Ozone Layer (R. G. Tanguay)

Clcan Oceans A Must

LOS: A Tiny Step

Remnants of War an Environmental Hazard

Shared Boundaries - Shared Resources (R. G. Tanguay)

Pahlavi Prize: Peter Scott, J.-Y. Cousteau Win

Dead not Alive for the Prince (R. G. Tanguay)

Water Conference (G. J. Cano)

Settlement of Disputes Relating to the Law of the Sea Convention (L. B. Sohn)

The 1977 Session of the United Nations Law of the Sea Conference (C. A. Fleischer)

Cared Natural Resources

UNEP's Expert Meeting on Liability and Compensation for Pollution Damage (E. Willheim)

United Nations Energy Institute Proposed

\section{INTERNATIONAL DEVELOPMENTS}

New International Qrder Club of Rome Special Meeting (C. W. Pinto)

IUCN Activities in the Field of Law (D. B. Navid)

Supranational Powers?

Réunion du Conseil Européen du Droit de l'Environnement (A.-C. Kiss) (Mecting of the European Council of Environmental Law)

MExico: A park for whales... and tourists and oil? (P. Heffernan) 17

Conférence internationale de Szombathely, Dialogue est-ouest T. Bakacs et A.-C. Kiss) (Szombathely International Conference. Dialogue east-west

Interparliamentary Conference on the Rhine Pollution (K. von Moltke)

A World Charter for Nature (N. Singh)

Legislation and Regulation of Waste Oil Disposal

Prieur, Hoeffler Awarded Haub Environmental Law Prize (R. G. Tanguay)

Environmental Simulation (M. Birr, D. Burkhardt)

Rencontre Est-Oucst (A.-C. Kiss)

Study Predicts Third World Disaster (M. Jahnke)

Sharing Jordan River Problems (J. Tamir)

Oil Spills: Convention to Limit Liability (C. A. Flcischer)

Protection de l'Environnement Marin - Zone Economique (A.-C. Kiss)
$1,49,97$

$1,49,97$

2

6
Lives and Deaths of the Great Whales - a report on the International Whaling Commission (M. McCloskey)

A Plea for a Conference of the Parties

OFCD Transfrontier Pollution

Environmental Measures and Alien Owners (R. Dolzer)

Bolivian Puma Fights Crime

Fundamental Principles of European Industry

An International Authority for the Marine Environment: A parliamentarian view (M. Remond-Gouilloud and W. E. Burhenne)

International Regulation of Chlorofluoromethanes (T. B. Stoel, Jr., R. I. Compton and S. M. Gibbons)

Les Ressources Naturelles et leurs Rapports avec le Droit de l'Environnement et le Droit International (Natural Resources and their relation with environmental and international law) (M. J. Magarinos de Mello)

Follow-up to Breshnev's Proposal

IUCN Elections Announced

The Canberra Inter-Parliamentary Meetings

\section{NATIONAL AFFAIRS}

Environmental Control for Hong Kong (J. McLoughlin)

France: Nouveau Contrat Social (New Social Contract)

Threat of River Pollution to Future Water Supplies (F. Sandbach) 32

Tobacco Smoking in Public Places (J. A. Vosburgh and L. B. Vosburgh)

Nouvelle Loi Relative aux Installations Classées (New Law on Hazardous Facilities)

Environmental Protection Strategy Assessment of Land Use Planning (W. J. Moshofsky)

Oil Tankers Need Safety Standards (S. W. Becker)

New Energy Saving Policies

Lake Nakuru: Flamingos Ivicted (H. Mitchell)

The Rights of Animal and Plant Life (P. van Heijnsbergen)

Japan

- Noisy Super Express (H. Hashimoto)

The Netherlands

- Private Owners Get Subsidies to Preserve Natural Arcas

France

- Défense de l'Environnement et Métamorphose du Droit des Associations (Environmental Protection and Metamorphosis of the Law of Associations) (M. Despax)

- La protection du Littoral (M. Prieur et A.-C. Kiss) (The Protection of the "Littoral")

-. France Makes Environment a Priority

Kenya

- Nakuru Update

- To Ban Hunting as a Measure to Conserve Wildlife: Wisdom or Folly? (B. Des Clers)

Canada

- Asbestos Emission Standards for Canada

- Northern Mines Must Wait

-- Oil Spills Technology

- Energy Self-Reliance in Canada

United States of America

- Amending the Clean Air Act: The Past is Prologue (G. L. Brady and P. B. Downing)

EPA Zero Emissions

- Carter Finergy Plan Criticized

- The Power of the Lobbies

- Physician Sentenced

- Environment Activities of the Marshall Fund

- Lack of Sites

- Proposed Regulations of Chlorofluorocarbons

- Safe Water

-.. Oceans Agency Rcorganized

Environmental Policy and Law, 3 (1977) 
- Dumping Deadline

-.. Projects, Policies and Environmental Impact Assessment: A Look Inside California's Black Box (G. Wandesforde-Smith)

Federal Republic of Germany

- Plant Emissions to be Analyzed

United Kingdom

- Proposed EEC Directives: Member States Balk (S. Nagel)

- Energy Conservation: How far should the law intervene? (J. C. Woodliffe)

\section{EUROPEAN COMMUNITIES}

The legal Basis for Environmental Policy (K. v. Moltke)

Treaty Amendment

Bird Protection

Polluter Pays

Environmental Cooperation with Switzerland

Incompatibility of the 16 th Amendment to the Italian Law on Hunting with the Commission's Proposal for a Directive on Bird Conservation

Treaty on Land-Based Mediterranean Pollution

EEC Admits Toxic Substances Regulations are Inadequate

Petition to Hault Erosion

\section{INTERVIEWS}

Norway's Environment Minister: Dr. Gro Harlem Brundtland Cecil Andrus: US Secretary of the Interior (W. E. Burhenne)

Mr. Russell Train (Former Administrator of the Environmental Protection Agency

Speech of Sir Peter Scott on being presented with the International Pahlavi Environment Prize for 1977

\section{NON GOVERNMENTAL ORGANIZATIONS}

Loudon New WWF President

UICN: Bilan Positif (A.-Ch. Kiss)

Strong to IUCN

\section{COURT CASES}

Transfrontier Pollution: Plaintiff can choose his court

\section{BOOK NOTES}

International Environment Programmes: A Guide to the Subject Matter

\section{SELECTED DOCUMENTS}

La Conférence Interparlementaire sur la Pollution du Rhin (Interparliamentary Conference on Rhine Pollution)

First International Symposium: Gray Whale

International Conference of Appellate Magistrates

La Pollution Maritime Provenant des Plates-formes de Forage en Mer (Sea Pollution Caused by Oil-drilling Platforms)

UNP Governing Council

Convention on Civil Liability for Oil Spills Committee on Environment

Revised Draft Convention on the Conservation of Migratory Species of Wild Animals

Explanatory Notes on Revised Draft Convention on the Conservation of Migratory Species of Wild Animals

Excerpt from Positive Economic Aspects of Environmental Protection - Research report of the Federal Ministry of the Interior (Germany) by Prof. W. Meissner and Prof. Erich Hödl 194

Resolution of the Executive Committee of the European Environmental Bureau on "the Fast Breeder Option in the Community Context"

Text of Tbilisi Declaration

Extracts from the Proposed New USSR Constitution on the Provision of Water and the Control of the Disposal of Wastes as Prerequisites to the Development of the Human Environment

European Industry and its Environment: The Fundamental Principles

'Industrie Européenne et son Environnement: Les Principes Fondamentaux

\section{(1)}

\section{Author Index of Volume 3}

Bakacs, Tibor, 20

Becker, S. William, 79

Birr, M., 71

Brady, Gordon L., 158

Brundtland, Gro Harlem, 40

Burhenne, Wolfgang E., 86, 126

Burkhardt, D., 71

Cano, Guillermo J., 66

Compton, Ruby I., 129

Connelly, Robert, 6

Des Clers, Bertrand, 155

Despax, Michel, 147

Dolzer, Rudolf, 120

Downing, Paul B., 158

Ducret, Clause, 6

Fleischer, Carl August, 3, 76, 100
Gibbons, Suedeen M., 129

Gour-Tanguay, Raymonde, 2, 8, 61

Hashimoto, H., 144

Heffernan, Patrick, 17

Heijnsbergen, P. van, 85

Kiss, A.-Ch., 16, 20, 74, 78, 151

Magarinos de Mello, Mateo J., 132

McCloskey, Maxine, 114

Mitchell, Heather, 50

Moltke, Konrad von, 22, 136

Moshofsky, William J., 37

Nagel, Stephan, 125, 175

Navid, Daniel B., 13

Pinto, Christopher W., 11
Prieur, Michel, 151

Remond-Gouilloud, M., 126

Rest, Alfred, 41

Sandbach, Francis, 32

Singh, Nagendra, 24

Sohn, Louis B., 98

Stoel, Thomas B., Jr., 129

Tamir, Josef, 75

Vosburgh, J. A., 34

Vosburgh, Ly-Beth, 34

Wandesforde-Smith, Geoffrey, 167

Willheim, Ernst, 109

Woodliffe, J. C., 177

Environmental Policy and Law, 3 (1977) 